\title{
9. Ross Stevens and Uni Tavur: A Kiwi publishing legacy among wantoks'
}

\section{ABSTRACT}

A pilot training project for Papua New Guinean journalists in New Zealand in 1974 ended as a failure. This led to a five-year New Zealand Government aid scheme to establish the South Pacific's first journalism school at the national University of Papua New Guinea in 1975. New Zealand journalist and broadcaster Ross Stevens was the founding lecturer and his legacy included Uni Tavur, the region's first independent newspaper produced by student journalists under an innovative ownership and editing model. The UPNG programme educated a generation of journalists in Papua New Guinea and today PNG journalists have the highest level of tertiary education and training in the Pacific. The experiment also had a profound impact on the traditions of free speech and journalism training for the rest of the Pacific region. This article examines the contribution made by the late Stevens and how the country's political pressures have impacted on his legacy.

\section{DAVID ROBIE}

Auckland University of Technology

\section{Introduction}

THEN A pilot training project for Papua New Guinean journalists in New Zealand ended as a failure, or even 'disaster', (Henshall, 1997: 97; King, interview with author, 2001) on the eve of PNG independence, the NZ Government responded to its local advisers and came up with an alternative plan. According to the late British journalism educator 
Peter Henshall, an experiment of sending 12 PNG journalists to New Zealand's Wellington Polytechnic in 1974 had the odds stacked against it anyway:

It proved too difficult for the students to make the necessary adjustments to the very difficult culture and climate, and at the same time cope with the demands of a course designed for people for whom English is not their first language (Henshall).

Following this disappointment, a decision was made to send a journalism trainer to Papua New Guinea, 'so that students could learn in the environment in which they would eventually make their living' (Ingram, 1986: 3). Journalism education and training was introduced at the University of Papua New Guinea at the beginning of 1975, when the New Zealand Government agreed to fund a one-year Diploma in Journalism course for an initial two-year period. New Zealand also provided the founding lecturer, journalist Ross Stevens, ${ }^{2}$ who later became one of Television New Zealand's leading current affairs reporters.

At the time, many journalists in Papua New Guinea were still expatriates. Training was a haphazard affair, with the handful of local reporters being trained in-house by the two principal employers of the period - the Office of Information and the National Broadcasting Commission (NBC). Approaching independence and the rapid expansion worldwide of the communications sector meant that PNG 'faced a serious shortfall in media personnel, in both quantity and quality' (Ingram). However, once established, the UPNG programme educated a generation of journalists in Papua New Guinea and today PNG journalists have the highest level of tertiary education and training in the Pacific. The experiment also had a profound impact on the traditions of free speech and journalism training for the rest of the region. This article examines the contribution made by the late Stevens, how the programme grew after he returned to New Zealand, and how the country's political pressures have impacted on his legacy. It is drawn, in part, from a section of the author's doctoral thesis (Robie, 2003).

\section{The context}

Papua New Guinea is the eastern half of New Guinea Island, a bridge between the South Pacific and Asia. Its territory is 461,691 square kilometres and the country has a population of just over five million - more than the combined

154 PACIFIC JOURNALISM REVIEW 10 (2) 2004 
populations of all other member nations of the regional political grouping, the Pacific Islands Forum (PIF). The country gained independence from Australia in 1975. It has:

- Two national daily newspapers (Post-Courier and The National);

- One national weekly newspaper (Wantok Niuspepa - a second weekly, The Independent closed in June 2003 after 23 years of publication. Word Publishing owned both);

- Four provincial newspapers, including the Eastern Star, Islands Post, Highlands Post and Mamose Post - the last three all provincial editions of the Post-Courier);

- One national television station - EMTV - broadcasting via satellite to the rest of the nation (and 12 other stations from the Asia-Pacific region received through satellite-cable);

A national public radio network - the National Broadcasting Corporation - which includes a shortwave service and a network of 19 provincial stations; and

- Two FM private radio systems.

The major print media in the South Pacific in the four key mass communication countries or territories in the region - Fiji, French Polynesia, New Caledonia and Papua New Guinea - have been 'largely dominated by foreign ownership' (Robie, 1995: 32). Global media magnate Rupert Murdoch has been the best-known player (owning the PNG Post-Courier through a News Corporation subsidiary, South Pacific Post Pty Ltd), but the Malaysian timber company Rimbunan Hijau owns the rival daily, The National. Australia's Channel Nine owns EM TV. NauFM (PNG FM Pty Ltd) is owned and managed by the Suva-based Communications Fiji Ltd group. In 1997, the radio broadcaster launched a second vernacular station, the Tok Pisin language YumiFM. In 2000, the NBC's FM station, Radio Kalang, was taken over by the national communications corporation, Telikom, to pay off outstanding debts.

Papua New Guinea has a Constitution that sets out the rights of its citizens and non-citizens who are within the country's boundaries. It was drawn up before independence in 1975 as a result of research and reviews by the Constitutional Planning Commission (CPC) and is thus often dubbed a 'home grown constitution'. Under Section 46 of the Papua New Guinea Constitution, the right of 'freedom of expression' extends to everybody, whether citizen or non-citizen. But this provision clearly states that the right can be limited by a 
law imposing restrictions. (For example, Section 38 is a general provision permitting restrictions over issues such as public safety or health.) According to a National Court judge Justice Teresa Doherty (1996), this section had not been arbitrarily breached by any Government, although there have been numerous threats by politicians to impose legislative gags, including the illfated Mass Media Tribunal Bill of 1987.

\section{An independence gift}

Ross Stevens was based at the University of Papua New Guinea as this was regarded as the only institution in the country capable of supplying necessary academic and training facilities to support the new journalism programme. Another early lecturer was Dr Michael King, the late NZ journalist and historian. In an interview before his death, King recalled that the idealism of the era stirred remarkable commitment about the potential for journalism to contribute to participatory democracy, 'and that's really why everyone was aiming as high as they were' (2001).

Former Vice-Chancellor Joseph Sukwianomb, who was a student leader at the time, recalls the heady independence days as a period when a weekly radio programme, University on Air, and newspaper, Uni Tavur, were launched, and 'journalism really came alive' (Sukwianomb, interview with author, 2001).

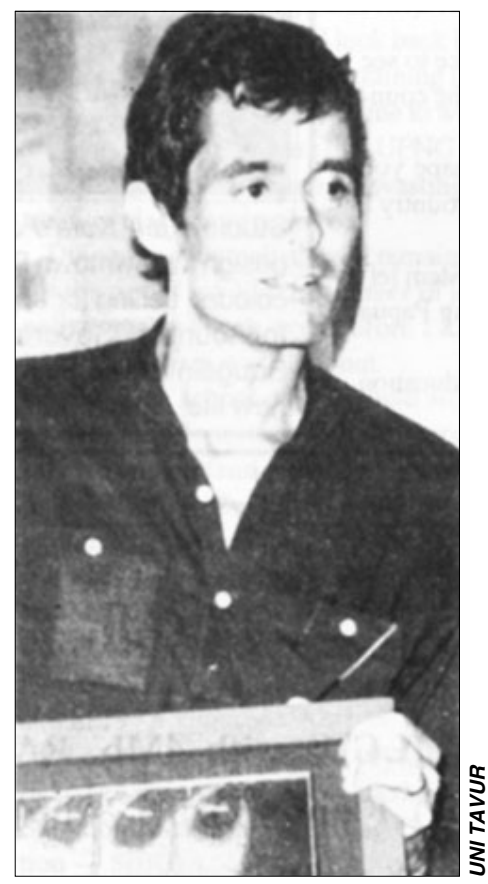

Ross Stevens: c. 1975.

Ross Stevens moved things, he organised programmes and set things up ... Ross is remembered now by many journalists working in media organisations, including John Somare, Joshua Kalinoe [now politicians], these were initial students who were also my friends. I remember the years 1975, 1976, $1977 \ldots$ these were very productive when journalism really came alive. Every Friday we were huddled around the 
radio [on $\mathrm{NBC}$ ] to listen to a programme that was put together by the students (ibid.).

Initially, the course ran for longer than the academic year, 'spilling over into the Lahara sessions at either side of Christmas' (Ingram, 1986: 3). Student journalists were given

basic training in the techniques of recognising, finding and writing news, reinforced with short attachments with media organisations while most of their fellow students were on holiday (ibid.).

The approach was regarded as having worked 'reasonably well', although from the start there was recognition that this programme was not enough. While successful students emerged after a year able to carry out the basic functions needed of a journalist, they were still 'immature and largely unskilled in any of the more advanced areas of journalism' (ibid.), such as specialist and feature writing, subediting and radio news production. For some time, the media industry lobbied to try to persuade the PNG Government and the university that better training was worth supporting and paying for. The New Zealand Government extended funding for the scheme by one year, until 1978, and then the PNG Government took over financial responsibility through its budgetary grant to UPNG. In the first three years of the school's existence, some 44 journalists undertook the course, several of whom had been in the profession for some time but who had had no formal media training. Michael King taught 22 journalism students in the first Lahara session at the start of 1976. He described them as 'bright and energetic' and wrote back to his family:

I get up sixish in the mornings, coolest part of the day, to do the bulk of my preparation and marking. Classes begin at $8 \mathrm{am}$. Everybody dresses casually (shorts, $\mathrm{T}$-shirts and jandals) which is a relief. The teaching day runs through to $4 \mathrm{pm}$. We're giving the group lectures on the principles of journalism, followed by immediate relevant exercises which we sub, correct, grade and get back to the class as quickly as possible. We also get them to report any functions that turn out to be on around the university or in town, and we invite people into the class for interviews and press conferences. This week there was an assembly of the Pacific Conference of Churches with over 100 delegates from all over the 
region. We generated some good work on the back of this and I brought Bishop Finau from Tonga into the class (King, 2001).

Sorariba Nash, a renowned short story author and current leader of the journalism strand at UPNG, was among the original students. He recalls that the school laid a foundation for journalism training, not only in Papua New Guinea, but also throughout the South Pacific.

I am very proud of the school. In 1975, it was established by the New Zealand Government as the pioneering journalism school in the Pacific. Not only did the school bring together Papua New Guineans, but all sorts of people from the rest of the region. I remember there was somebody from Kiribati, the Solomon Islands, Samoa, many of our colleagues out there now working in big positions in Government and the private sector - they all benefited from this school. I see it as an independence gift. It was the best gift because the school has survived all these years and produced so many journalists (Sorariba, interview with author, 2001).

But the task was not easy. Stevens and his colleagues encountered 'a surprising amount of racism' (King, 2001) among the old expats, mostly Australian, including some journalists, and needed to work around that without provoking them. They also needed to deal with prejudice against journalism education at a university. At the time, New Zealand had only one journalism course based at a university, the University of Canterbury postgraduate journalism programme, and this was regarded with some scepticism in some media industry circles (Newth, 1997). Even in Australia, university journalism education was still in its relative infancy.

The whole idea of putting journalism into the context of university education still ran counter to the perceptions of the New Zealand journalism industry at that stage that you best learn about the job on the job. And I would have thought probably among the network of existing working journalists in Papua New Guinea at the time, too. But I'm not really sure about that. I can remember we got a bit of scoffing from the journos at the Post-Courier and the NBC, and these tended to be expatriates, and almost all Australians, and they weren't especially complimentary about:

- training journalists in a university context, and 
- about the idea of training indigenous journalists in a university context (King, 2001).

Sorariba was among many journalists of the era who was grateful for the pioneering efforts of Ross Stevens. To them, the whole concept of journalism when they entered the school was new. 'We didn't know that you had to go to Parliament and face parliamentarians,' recalled Sorariba. 'You had to go to court. You even had to argue with taxi drivers'. Stevens, and his practical style that involved a lot of off-campus work, doing interviews, left a lasting impression. ${ }^{3}$

I think it was his character, the leadership that he demonstrated what a journalist should do, that provided a model. It was quite new to us. We come from a cultural background where we are shy, we don't shout at people, we don't talk a lot. The way Ross Stevens took us around Port Moresby during training, doing practical work, set the pace, gave us that example as a journalist - and the courage.

Ross ... was more or less our role model, for those of us who attended the school - the first lot. We wanted to be like him. He played a very important role and I am grateful for his presence (Sorariba, 2001).

Michael King shared the impressions of Sorariba and many others about the vital role Stevens played in establishing the programme.

Ross Stevens had considerable charisma, as well as having considerable integrity. He made a huge impact on everybody — the students in one direction, but also all the people he had to deal with in officialdom, either in the Office of Information, the NBC, or the university. He just had a kind of naturally authoritative and diplomatic manner. I have got absolutely no doubt that one of the reasons things moved with such momentum was that he had absolutely the right set of qualities for doing that job (King, 2001).

King regarded 'Ross's stature, commitment and expertise' as an 'enormous factor in the whole thing working' (King, 2001). He noted that by the time he arrived in Port Moresby after a year that Stevens was already speaking Tok Pisin, and some Motu. 
The fact that he had made that effort too, was an indication of how committed he was to the job. It actually gave him a facility to talk to indigenous people across the cultures because of Tok Pisin being the lingua franca, whereas anybody else in his position would have had to reply to an interpreter (King, 2001).

There were also high and idealistic expectations on the media in this emerging nation. 'Founding father' Sir Michael Somare, Papua New Guinea's first and current prime minister - and himself a former radio journalist, told a seminar on the mass media and human development a month before independence that the role of news organisations was vital in building the nation.

The mass media aims to reflect human development, but its role goes far beyond that. All reporting through the media, however, impartial, is selective. Because it is selective it influences our development, in particular directions ... Many Papua New Guineans have developed a liking for fast cars and tailor-made cigarettes. It is the media of films and advertising which has helped us to develop this liking (Somare, 1975:4).

Drawing on his broadcasting background, Somare warned about the damage that could be caused by media not offering a 'correct balance' for the nation.

It is my fear that radio advertising will destroy the balance that will allow human development in Papua New Guinea to be that of future comfort and happiness. I believe that advertising on radio, because it reaches into so many homes, will increase the materialist cult in Papua New Guinea and by its methods destroy many of our spiritual supports (Somare: 5).

\section{Uni Tavur - an independent newspaper tradition}

The training publication Uni Tavur, which played an important role in the formation of journalists over the next two decades, was founded during the Stevens era. Tavur means 'conch shell' in the Tolai language of the Gazelle Peninsula, East New Britain. The shell became the paper's masthead logo. Journalism student Robert Elowo, who died in a tragic car accident in 1976 while working for NBC's Radio Kundiawa, designed the original version. Uni is derived from the university (Waibauru, 1994). Uni Tavur was launched on 24 July 1975. The first newsroom was set up in 'the dungeon' - as the students dubbed the bunker style classroom near the Michael Somare Library. The first 
edition carried news items, including social and sports events. It consisted of four A4 size pages and had a circulation of 200 copies. Over the following years, Uni Tavur faced many changes. Student reporters were assigned to rounds with a brief to cover anything of news value for their readers. Recalled Sukwianomb:

Uni Tavur came ... to play a significant role in the university scene in terms of changing ideas ... generally about that period from independence ... the campus was very vibrant, very active. The students were well aware of what was happening. This was the time of student demonstrations and

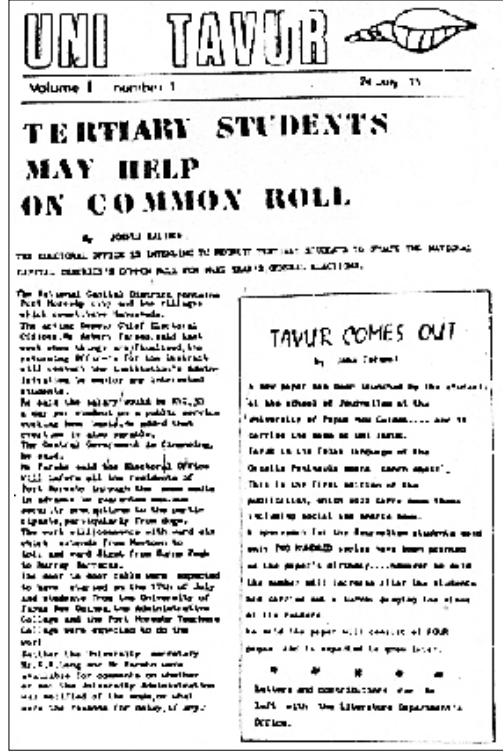

Uni Tavur in 1975. strikes. They were all reported from student angles by student journalists (Sukwianomb, 2001).

'Whether it was life on campus, life on the borderline, the political scene or anything of national interest, the students sweated to get the paper going,' wrote first-year journalism student Jessie Waibauru in the 20th anniversary issue (Waibauru, 1994:88). In a retrospective survey of Uni Tavur over the years, she captured the essence of a lively publication and a snapshot of history. Starting in 1975, reports focused on Sir Michael Somare leading the country to independence on September 16, and the selection and swearing in of the first PNG Governor-General, Sir John Guise.

Letters to the editor caused some laughs. According to one correspondent in 1975: 'I've followed the progress of Uni Tavur since its establishment with a great deal of interest. However ... my criticism is directed at the use of phrases such as "other sources", "one informant", "unknown sources", "it is believed", "a source close to Uni Tavur" etc ... Your anonymous source is like a man whose wife has run away from him. And who then asks someone else to go and beat up his wife because he's 
afraid she might bite. He's a "rubbish man", and you'll find his opinions or statements - even if they sound important - are worthless, and of lesser news value too' (Waibauru: 90).

In 1978, Uni Tavur reported about Papua New Guinea moving to support the 'Kanak Liberation Movement' fighting for independence for New Caledonia from France. During the same year, an arts student said that marijuana should be legalised in Papua New Guinea because it was 'not as bad as beer'. In 1979, a second-year student in social work said he had found a frog's head in his plate of food. When the mess manager was asked about it, he reportedly said it was 'an oyster'. In 1981, Student Representative Council (SRC) president Gabriel Ramoi criticised the lecturers' manner of dressing, while a commerce student alleged the Government had wasted millions of kina by recruiting overseas specialists to improve accounting systems. Just six years later, Ramoi as a young Communications Minister tried to introduce the notorious 'Ramoi Bill', the draft Media Tribunal law that would have ushered in draconian curbs on the news industry.

The following year the library display on smoking caused a smoky nightmare for smokers. The headlines read: YOU CAN'T SCRUB THE SMOKERS ...TRY SOME, SMOKERS TAKE IT REGULARLY ... HAPPY BIRTHDAY SMOKERS and, to top it off, KISSING A SMOKER IS LIKE KISSING AN OLD ASHTRAY. During the same year, in March 1982, UPNG students paid tribute to the late Gabriel Gris, the first Papua New Guinean Vice-Chancellor, who died suddenly.

In 1992, the newspaper flirted with 'yellow journalism', printing on canarycoloured paper stock. At the time of its 20th 'birthday', in 1994, Uni Tavur was reporting about the Bougainville conflict and corruption. According to Waibauru:

Twenty years this week sees a different Uni Tavur with modern equipment to facilitate the production. The newspaper has improved, not only in size, but also the quality of the reports. There has been a significant change because of desktop publishing. The content has also changed dramatically. It now has advertisements (Waibauru: 91). 
Ross Stevens was among the many who sent messages of congratulations to Uni Tavur to mark its 'two decades old' special issue. His message arrived late so it was published in the edition of 19 August 1994. He appealed to the Papua New Guinean news media to continue valuing a good tertiary education for the "most important profession of all. The one that "keeps the bastards honest":

\section{[Is] Uni Tavur 20 years old? Is it that long since I arrived in Port Moresby? Long since I first felt that hot blast of the Port Moresby noon on my pale Southland cheeks? Twenty years since I met Olive Tau}

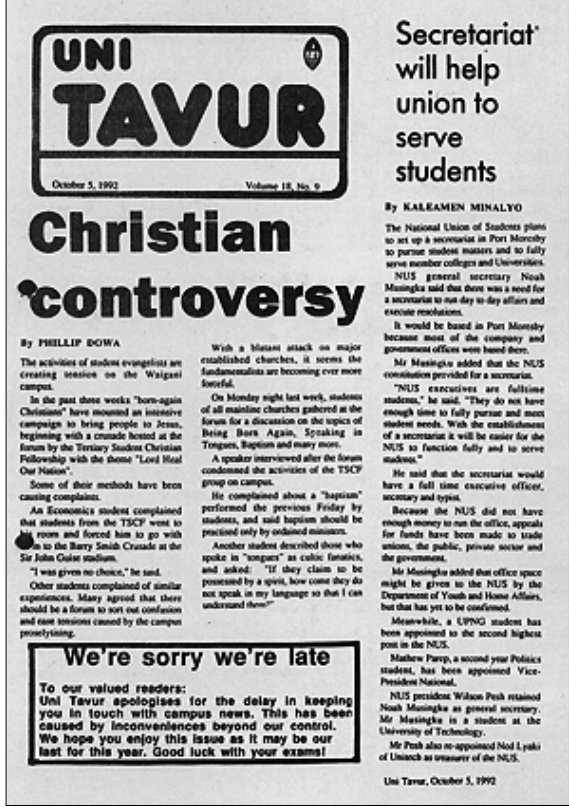

Uni Tavur in 1992.

carrying a typewriter on her Hanuabada head; Tabo Epita beside her showing Kavieng air is just as good as carrying an Olympus portable? Does anyone now - in the age of Apple - remember what an Olympus portable is? And is it really 20 years since I asked Geoff Heard, then carrying the odd title of 'cadet counsellor' to the NBC newsroom, whether he wanted me to teach news writing and news style in a 'Melanesian Way'? (The answer incidentally was No!) (Stevens, 1994: 9).

Another message came from Vice-Chancellor Joseph Sukwianomb, who described two decades of publishing Uni Tavur as a 'remarkable feat' for a small newspaper.

When the first copy of the first edition of Uni Tavur ran off the press, the pioneers of that historical epoch perhaps did not think that there would be many more copies, and 20 years to live on ... Survival of a project such as Uni Tavur has also symbolised the growth of specialist training for journalists in this country (Sukwianomb, 1994: 17). 
The following year, the real anniversary, saw Uni Tavur go tabloid, boost its circulation to 2000 , begin printing fortnightly editions on newsprint with the Post-Courier, and introduce a liftout investigative reporting section called 'Insight'. It was a model for student media ownership and editorial independence in the South Pacific. The paper went on to win the 1995 Ossie Award from Australia's Journalism Education Association (JEA) for the best regular publication in Australia, New Zealand and the Pacific (Uni Tavur takes out top award, Post-Courier, 1996). The judge, Max Suich, editor-in-chief of Sydney's The Independent Monthly, said: 'By far the most impressive was the

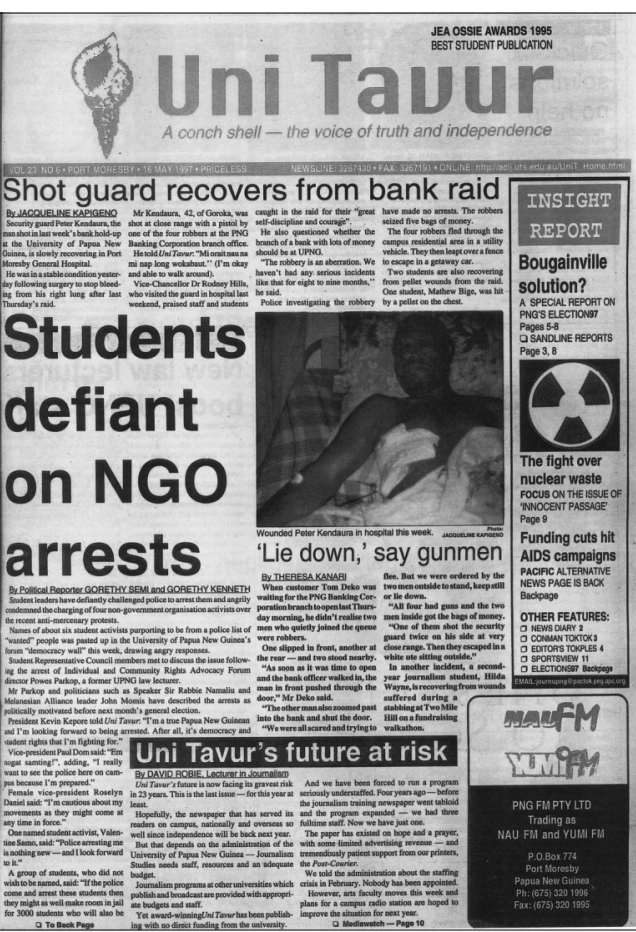

Uni Tavur in 1997. University of PNG newspaper, which had a level of maturity in its writing, and a concern with national issues, that made it stand head and shoulders above the others' (ibid.). In 1997, the newspaper's student journalists covered the Sandline mercenary crisis.

In spite of a lack of facilities, the journalism programme peaked in 19934 with more than 70 students and the highest ever number of degree graduates, although attempts were made to reduce this to a more manageable number in following years. Over the next five years, the UPNG journalism programme succeeded in gaining funding that totalled more than K71,000 to upgrade facilities, including an Apple Macintosh desktop publishing newsroom, the establishment of a radio station, and the first newspaper website in the South Pacific (established for Uni Tavur in a partnership with the University of Technology, Sydney, in 1995). Donors included the New Zealand High Commission, the Canada Fund, the Post-Courier, the Communication Assistance Foundation (CAF) of the Netherlands. The Post-Courier introduced an 
annual subsidy of K5000, initially for equipment such as computers, and later a printing credit for Uni Tavur (Robie, 1997: 100). The daily newspaper also offered similar assistance to Divine Word University's Liklik Diwai in Madang.

In February 1995, the first news tabloid edition of Uni Tavur with fourcolour news pictures on the front page rolled off the Post-Courier press. The new-look Uni Tavur was launched by the South Pacific Post Pty Ltd's administrative manager, Luke Sela. In terms of accountability and guidelines, Uni Tavur was at the time the only newspaper in the South Pacific to have an 'editorial charter', a mechanism used increasingly in many countries to establish editorial quality. The paper also observed the Charter of Student Press Rights in accordance with the spirit of the United Nations Convention of Freedom of Information. The newspaper's slogan was 'A conch shell ... the voice of truth and independence'.

In June 1995, Uni Tavur won an award for the best community/student newspaper in the PINA Pacific Media Awards in Port Moresby. The paper also won the 1995 Ossie Award for best regular student publication (see Table 1). The programme's regional Pacific profile was enhanced. Courses were also revamped and consolidated, including the establishment of two new specialist advanced programmes, Certificate in Investigative Journalism and Certificate in Public Relations. The first batch of about a dozen public relations graduates joined mining companies and other corporate entities at the end of 1995.

After a period during 1995 when Deputy Vice-Chancellor Nick Kuman acted as chief executive of the university, Sukwianomb, who had been a strong supporter of journalism from the days when Stevens founded the programme, was replaced by an expatriate Australian who had distaste for the media. Dr Rodney Hills, a onetime Australian High Commissioner in Tonga and former head of the AusAID Pacific training school in Sydney, became Vice-Chancellor in early 1996. This development took place as UPNG headed towards major restructuring and cutting of programmes and Hills believed journalism had no place in a university.

In the second semester of 1997, Uni Tavur suspended publication when funds were frozen and the restructuring plans for the university took greater priority. In the final edition of the year, in October, students who had petitioned Dr Hills over a shortage of lecturers and equipment went public with their appeal. The UPNG University Council claimed the planned closures were part 


\begin{tabular}{|l|l|l|l|l|l|}
\hline \multicolumn{5}{|c|}{ Table 1: Training publications in Papua New Guinea, 1975-2002. } \\
\hline University & Publication & $\begin{array}{l}\text { Online } \\
\text { edition }\end{array}$ & $\begin{array}{l}\text { Format; } \\
\text { frequency }\end{array}$ & $\begin{array}{l}\text { Printer; } \\
\text { print run }\end{array}$ & Donor \\
\hline $\begin{array}{l}\text { UPNG } \\
\text { (Port } \\
\text { Moresby) }\end{array}$ & $\begin{array}{l}\text { Uni Tavur' } \\
1975, \\
\text { (founded by } \\
\text { Ross Stevens }\end{array}$ & $\begin{array}{l}\text { Uni Tavur } \\
\text { Online, 1995 } \\
\text { (founded by } \\
\text { David Robie }\end{array}$ & $\begin{array}{l}\text { Tabloid, } \\
16-24 \mathrm{pp}, \\
12 \text { issues }\end{array}$ & $\begin{array}{l}\text { Post-Courier } \\
\text { (from 1995); } \\
2000 \text { copies } \\
\text { a year }\end{array}$ & $\begin{array}{l}\text { Communication } \\
\text { Foundation } \\
\text { (Netherlands) }\end{array}$ \\
\hline $\begin{array}{l}\text { DWU } \\
\text { (Madang) }\end{array}$ & $\begin{array}{l}\text { Diwai, 1982, } \\
\text { (founded by } \\
\text { Fr Frank } \\
\text { Mihalic }\end{array}$ & None & $\begin{array}{l}\text { Tabloiid } \\
12 \text { pp } \\
4 \text { issues } \\
\text { a year }\end{array}$ & $\begin{array}{l}\text { Post-Courier } \\
\text { (from 1998); } \\
1000 \text { copies }\end{array}$ & $\begin{array}{l}\text { Pacific Islands } \\
\text { (PINA) Assn }\end{array}$ \\
\hline
\end{tabular}

${ }^{1}$ Winner of the JEA Ossie Award for best publication, 1995.

of cost-cutting measures following severe budget cuts to UPNG in the 1999 year. But the action led to academic staff at UPNG criticising what they described as a 'rush decision to axe facilities' (Nuia, 1997: 5-8). The PNG Media Council also expressed alarm over the strategy adopted by the council to cope with funding crises. Council president Luke Sela said in a statement that the cutting of courses, whether for intending first-year students, or in midstream, would

bleed future generations of the most valuable asset - knowledge ... The closure of the journalism course is a direct attack on media freedom (ibid.).

For Sorariba, 1999 was a difficult year trying to keep Uni Tavur alive. From the moment that the University Council decided on January 25 to 'abolish Journalism Studies at UPNG and transfer the students to Divine Word University', he thought the programme's days were numbered. He recalled:

There was a silence when a lot of us involved in this cost-cutting exercise were throwing back and forth arguments: Could you consider this [to be] a restructure package? We're cutting this? How about taking us back? Leave us alone sort of thing (Sorariba, 2001).

Associate Professor Frank Morgan, chair of Communication and Media Arts at the University of Newcastle, Australia, and then president of the Interna- 
tional Association for Media and Communication Research (IAMCR), joined in the chorus of voices defending the programme with an article (1999) published two weeks later in The National, saying:

AusAID's recent report on Australian aid to Papua New Guinea calls for the reduction of poverty through sustainable development. That objective is clear and readily agreed. The question, however, is how? And virtually every conceivable answer argues for maintaining UPNG's world-renowned journalism programme, not scrapping it...

Morgan added:

UPNG may well, as The National observed [January 27], 'simply be following worldwide practice by choosing the easiest options'. It may also be falling for the confidence trick of economic rationalism that costreduction improves cost-benefit ratios by reducing them. Nothing, however, is for nothing. Ultimately, zero cost leads to zero benefit and zero divided by zero soars to infinity (Morgan, 1999).

The long wait continued all year, including protests by the campus students, eventually leading to the resignation of Dr Hills in May and his departure for Dubai. Finally, the University Council resolved early in 2000 to reverse the earlier decision and the journalism programme was allowed to remain at UPNG after all, 'as long as it was restructured as part of the general costcutting' (Sorariba, 2001).

\section{Conclusion}

The University of Papua New Guinea played a crucial pioneering role in the development of journalism education and training, not only for Papua New Guineans, but also throughout the South Pacific region. For many years it was the benchmark for tertiary journalism qualifications and analysis of media industry standards. The initiative by the New Zealand Government to set up a journalism school at UPNG in 1975, after a pilot training project for Papua New Guinean journalists in Wellington ended in failure, was an innovative move years ahead of its time. Much of the early success of the programme was due to the inspiration and dedication of the founding lecturer provided by the aid project. Ross Stevens had just the 'kind of naturally authoritative and diplomatic manner' needed to make the school work (King, 2001). 
Although the UPNG journalism programme lacked facilities and resources, it was innovative and vigorous and established an international reputation. Among its achievements were a high profile and award-winning training newspaper, Uni Tavur. Indeed, this was an early model for a recent trend in New Zealand for journalism schools to publish in-house training newspapers, notably Auckland University of Technology with Te Waha Nui and Waikato Institute of Technology in 2004. Uni Tavur became the first student journalism publication in the Pacific to gain an international award. It was relaunched as a tabloid printed by the Post-Courier in 1995. Success appeared to come in cycles and this was directly related to periods when highly committed staff joined the university. Such periods included Peter Henshall and David Ingram's tenure in the late 1980s and the author's own contract at UPNG along with Sorariba Nash in the mid-1990s (see Robie, 2003: 199-238). By the end of 1997, when UPNG began restructuring its courses and the Journalism Studies programme ceased to have its long-established autonomy, some 174 journalists had graduated with journalism degrees or diplomas. This contribution was then - and even today - by far the largest share of qualified journalists produced by any institution for the South Pacific.

\section{Notes}

1 'Wantoks' speak a common language - in Tok Pisin, literally 'one talk'; the word is also used more loosely to describe a 'brotherhood', clan or extended family. 'Bigmen', usually chiefs or leaders, were often protected and encouraged by the Australian colonial authorities and later became very powerful or wealthy. See Bernard Narokobi (1983). The Melanesian Way. Port Moresby, Papua New Guinea: Institute of PNG Studies; and Suva, Fiji Islands: Institute of Pacific Studies, University of the South Pacific, pp 13-14.

${ }^{2}$ Ross Stevens died from cancer, aged 50, in July 1997 at the peak of his career with the TVNZ current affairs programme Assignment. Ironically, another leading journalism educator UPNG, Peter Henshall, a key figure in the late 1980s, died shortly after leaving Papua New Guinea. He collapsed on a British tennis court at the age of 42 . Michael King and his wife, Maria Jungowska, died in a tragic car accident in New Zealand in March 2004.

${ }^{3}$ Stevens later returned to Papua New Guinea in July 1985, a decade after establishing the journalism school. He was commissioned by the NZ Coalition for Trade and Development to complete a Pacific-wide survey of United Nations development programme work in the region begun earlier that year (see Stevens, 1986). 


\section{References}

Doherty, T. (1996). Basic Rights - The Courts and the Media. In Millett, John (ed.), Freedom at the Crossroads: The Media and the Constitution. Port Moresby: Discussion Monograph No 66, Institute of National Affairs, August.

Henshall, P. (1997), The origins of journalism education in UPNG, Pacific Journalism Review, 4 (1): 97-98. Originally published as part of a paper, Journalism Education and Training at the University of Papua New Guinea. In Pacific Islands Communications Journal, (1988), 15 (2): 32-39.

Henshall, P., and D. Ingram. (1992). The News Manual (three volumes). Port Moresby: Poroman Press.

Henshall,P. (1989). ANews Agency for Papua New Guinea. Published MA thesis. Port Moresby: University of Papua New Guinea Press and UNESCO.

Ingram, D. (1986). Training for journalism. Paper presented at a Mass Media and National development seminar organised by the Hans Seidel Foundation, Port Moresby, April 7-8.

King, M. (2001). Audiotaped interview with the author. Opoutere, NZ, June 23.

Kuman, N. (1995). Memorandum to UPNG journalism lecturers, August 14.

Moore, C. (1995), Journalism as a foreign language. In David Robie (ed.), Nius Bilong Pasifik: Mass Media in the Pacific (pp 63-72). Port Moresby: University of Papua New Guinea Press.

Morgan, F. (1999, February 9). The need for journalism course. The National.

Narokobi, B. (1983). The Melanesian Way. Port Moresby, Papua New Guinea:

Institute of PNG Studies; and Suva, Fiji Islands: Institute of Pacific Studies, University of the South Pacific.

Newth, K. (1997). Tertiary training: A history of university journalism courses in New Zealand, New Zealand Journalism Review, Vol 5, (Spring), pp 45-53.

Robie, D. (2003). Journalism Education in the South Pacific, 1975-2003: Politics, Policy and Practice. Unpublished PhD thesis. Suva: Department of History/Politics, University of the South Pacific.

Robie, D. (1997). Electronic Student Newspaper: Uni Tavur and Pedagogy of Experience. AsiaPacific MediaEducator, January-June, Issue 2, 121-125.

Robie, D. (ed.) (1995). Nius Bilong Pasifik: Mass Media in the Pacific. Port Moresby: University of Papua New Guinea.

Seward, R. (1999). Radio Happy Isles: Media and Politics at Play in the Pacific. Honolulu: University of Hawai'i Press.

Somare, M. (1975). Mass media and human development. Paper presented at the Mass Media and Human Development in the South Pacific Context conference, Bomana, Port Moresby, August.

Sorariba, N. (2001). Audiotaped interview with the author, Port Moresby, May 4.

Stevens, R. (1995, August 19). Tales of Olympus days to Apple. Uni Tavur.

Stevens, R. (1986). The United Nations Development Programme in Papua New

Guinea: Three Case Studies, Wellington: New Zealand Coalition for Trade and

Development (NZCTD) Pacific and Research Project.

Sukwianomb, J. (2001). Audiotaped interview with the author, Port Moresby, May 3. 
MEDIA OWNERSHIP AND DEMOCRACY

Uni Tavur takes out top award. (1996, May 3). Post-Courier.

Waibauru, J. (1994, July 22). Frog's heads, old ashtrays and politics.Uni Tavur, p 1011.

Dr David Robie was coordinator of the University of Papua New Guinea journalism programme in the early 1990s. This article is a revised version of a presentation drawn from part of a chapter in his doctoral thesis, Journalism Education in the South Pacific, 1975-2003: Politics, Policy and Practice. The presentation was delivered at the Journalism Education Association of New Zealand (Jeanz) conference at New Plymouth, 5-6 December 2003. david.robie@aut.ac.nz

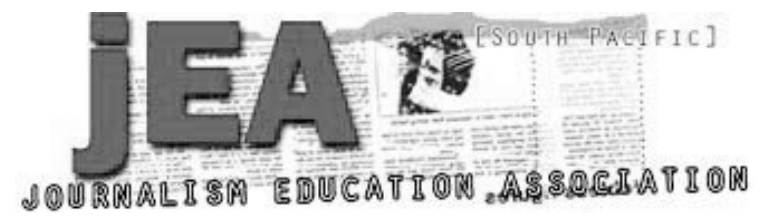

The Journalism Education Association (JEA) Conference 2004 is in the Fiji Islands on December 3-8. Hosting the conference is the University of the South Pacific Journalism Programme and the theme is "Media literacy in the Pacific and Asia".

Details on these websites:

JEA:

www.jea.org.au

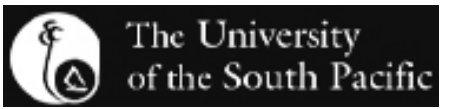

Pacific Journalism Online (USP): www.usp.ac.fj/journ/ 